\title{
Continuidade e mudança no Norte da Lusitânia no tempo de Augusto
}

\author{
Armando REDENTOR \\ Universidade de Coimbra \\ aredentor@gmail.com \\ Pedro C. CARVAlHo \\ Universidade de Coimbra \\ pedrooak@gmail.com
}

\begin{abstract}
RESUMO
A época de Augusto nos territórios do Norte da Lusitânia é avaliada do ponto de vista do registo arqueológico e a partir da documentação epigráfica regional referente ao fundador do império, analisando-se, em síntese, o processo de integração territorial e o estabelecimento de um novo quadro de povoamento, notando as nuances percecionáveis entre o litoral e o interior num cenário que se afigura de continuidade e de mudança.
\end{abstract}

Palavras chave: Lusitânia setentrional. Augusto. Povoamento. Epigrafia.

\section{Continuity and Change in Northern Lusitania under Augustus}

\begin{abstract}
This text focuses on the archaeological traces in the northern territories of Lusitania during the Augustan period, based on regional epigraphic documents relating to the founder of the Empire. The process of territorial integration and the establishment of a new framework for population settlement are briefly presented, and the analysis points to the perceptible nuances between the littoral and the interior in a scenario of both continuity and change.
\end{abstract}

Key Words: Northern Lusitania. Augustus. Settlement. Epigraphy. 
O Norte da Lusitânia aqui versado corresponde à dimensão territorial atualmente portuguesa setentrional ao paralelo que podemos traçar pelo troço do Tejo que as fronteiras políticas hodiernas consideram internacional, indo até ao curso do rio Douro, ultrapassando-o, em parte, a montante da foz do Tua (Fig. 1). ${ }^{1}$

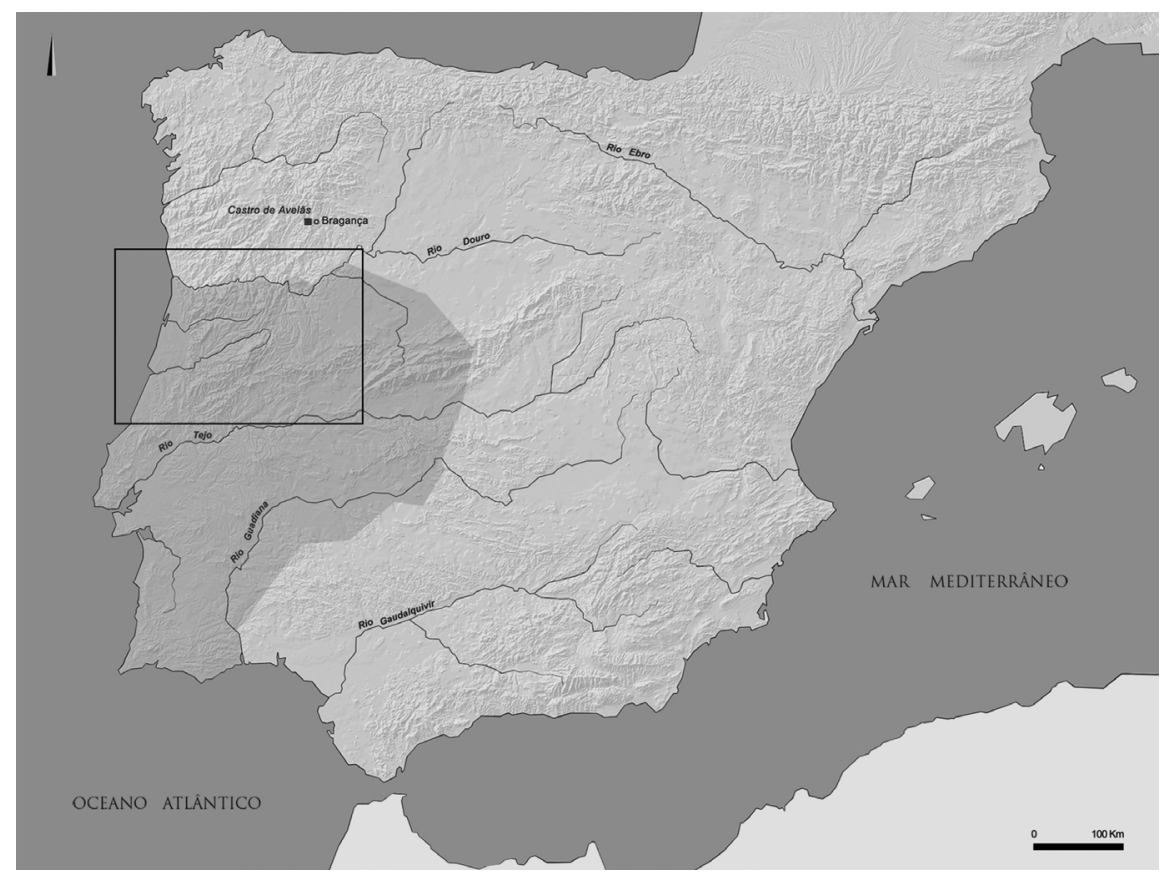

Fig. 1. O Norte da Lusitânia romana no contexto peninsular.

O povoamento dos territórios ocidentais imediatamente abaixo do curso Douro, centrado em núcleos de povoamento indígena associados a povoados fortificados expõe afinidades com o mundo castrejo, considerando mesmo alguns investigadores, na esteira de uma proposta fundadora de López Cuevillas, ${ }^{2}$ ter a designada cultura castreja, extensão meridional até ao rio Vouga, alargando-se às serras de Montemuro, Freita e Gralheira até à do Caramulo. ${ }^{3}$ Mais para o interior, o rio Águeda e as terras do Alto Coa terão de alguma forma funcionado como linha de fronteira mais ou menos difusa entre comunidades associadas à entidade étnica dos Vetões ${ }^{4} \mathrm{e}$ as que

1 A questão dos limites da Lusitânia neste sector setentrional, concretamente com a Astúria, após a sua oficialização como província sob Augusto, continua ser objecto de alguma controvérsia, entre os que apontam o curso do Douro como fronteira e os que admitem que esta seria mais setentrional no sector a oriente do vale do Tua. Cf. Alarcão et Ali 1990; Lemos 1993 Ib, 485; Guerra 1998, 328; Redentor 2008, 105-106; REDENTOR 2011, I, 25-60; LEMOS ET ALII 2012.

2 López Cuevillas 1933, 105-106.

3 V. g. SiLva 2007, 13-15, considerando o Noroeste português como subunidade da área meridional castreja; QueIRoga 1992, 11.

4 Osório 2009. 
configuram a realidade territorial do interior lusitano, ainda incipientemente caracterizadas, mas onde o povoamento amuralhado associado a implantações topográficas diversificadas, concentrado em áreas mais favoráveis em termos de recursos, e a uma ergologia que continua mal conhecida, também caracteriza o período do Ferro Pleno até à presença romana na região, ${ }^{5}$ no final do qual a senha identitária de Lusitani se faz presente. ${ }^{6}$

Os tempos augustanos no Norte da Lusitânia, terão sido, decerto, de decisiva mudança, por entre permanências estruturais cimentadas na realidade social e de povoamento indígenas. Esta, tal como outras paisagens provinciais, aparecerá como resultado de um compromisso entre as formações sociais autóctones, com suas dinâmicas próprias, e o poder de Roma. Mas cedo se assistirá a uma metamorfose social e política, associada à implementação de uma estrutura administrativa integradora das realidades territoriais que foram ampliando o domínio de Roma para o Ocidente.

Assim, na nova era vivida pelo territórios lusitanos norte-ocidentais, a implementação de uma estrutura administrativa que servisse o esforços de integração e os interesses (múltiplos) de Roma e do imperador torna-se fundamental, naturalmente associada à criação de uma rede de estradas que aproximasse espaços e acelerasse a exploração dos recursos desses territórios, polarizados numa rede de civitates/cidades.

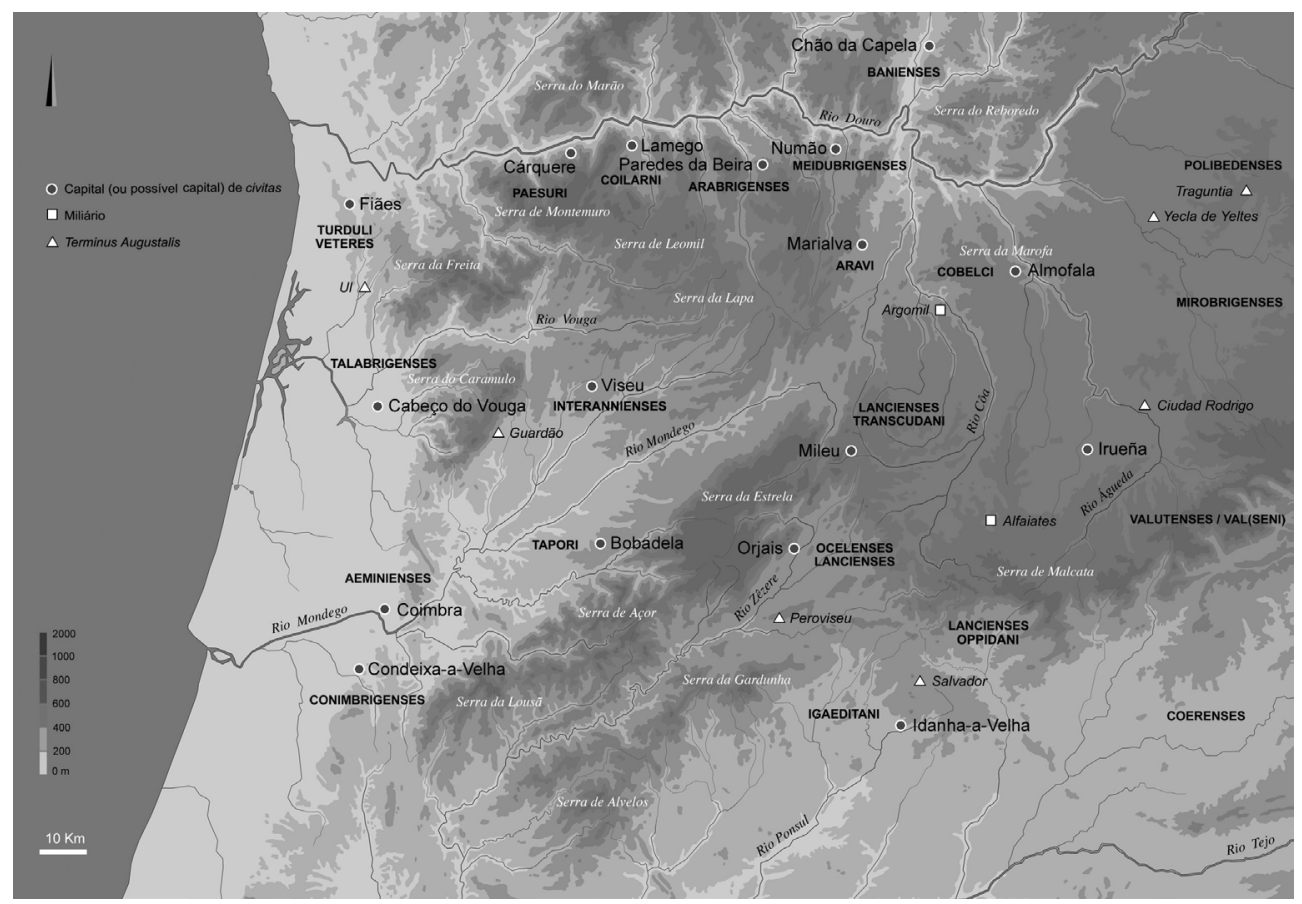

Fig. 2. O Norte da Lusitânia: civitates e epigrafia augustana.

5 Silva 2005, 68-100; Carvalho 2007a, 55-86.

6 Alarcão 2001. 
A figura do imperador, de César Augusto, avulta nestes esforços iniciais, como mui bem ilustram as fontes epigráficas que temos ao dispor. E isso não será de espantar, pois o que está em causa é a integração de territórios novos, que é necessário sujeitar, e, simultaneamente, a afirmação de Augusto no novo modelo político de que ele é a figura cimeira. Paradigmáticos a este respeito são, desde logo, os termini Augustales que em época augustana se erigiram em diferentes pontos do Norte lusitano (Fig. 2), com linguagem condensada e função muito concreta.

No território português integrado na Lusitânia setentrional conhecem-se quatro textos referentes a documentos deste tipo, havendo a acrescentar que são integráveis numa série maior que inclui mais cinco, localizados nos atuais territórios de Salamanca e de Ávila. ${ }^{7}$ Todos eles se encontrariam dispersos em pontos que terão coincidido com linhas de fronteira entre civitates, assumindo-se, em termos práticos, como marcos delimitadores.

Dois dos que têm correspondência com o atual território português, cujo texto nos chega completo, e que são os mais meridionais no contexto que referimos, estabelecem a divisão entre a civitas Igaeditanorum (cuja capital se reconhece, sem sombra de dúvida, em Idanha-a-Velha) ${ }^{8}$ e a civitas, ou civitates, que está, ou estão, a norte, pois se num caso, o de Salvador (Penamacor), ${ }^{9}$ com rigor se referem os Lancienses Oppidani, no outro, o de Peroviseu (Fundão), ${ }^{10}$ apenas se regista que a divisória se estabelece inter Lancienses et Igaeditanos.

A proximidade geográfica entre ambos associada à referência singela a Lancienses poderia, por si só, sugerir que ambos estavam implantados numa mesma linha de fronteira. Mas não quererá dizer a ausência da abreviatura $O P P($ idanos $)$, e restantes diferenças notórias na paginação, ${ }^{11}$ bem como a diferente datação, distintamente plasmada no número de poderes tribunícios, que remete para uma comunidade diferente dos Lancienses Oppidani? Não entraremos na revisão da problemática atinente a este tema, mas, para além dos Oppidani e dos Transcudani, com localização setentrional aos primeiros e associada ao Alto Erges, tocando a ocidente o Alto Coa, cabe equacionar a existência, em época augustana, de uma terceira comunidade de Lancienses, ditos Ocelenses, como têm vindo a defender alguns investigadores, ainda

7 Os restantes termini Augustales lusitanos da época de Augusto, situados em actual território espanhol, são os seguintes: Ciudad Rodrigo (CIL II, 857 e 858), Ledesma (CIL II, 859), Traguntia (CIL II, 5033), e Jarandilla de Vera (HEp 13, 242; GómEZ-PANTOJA 2011). Sobre o tema, citamos apenas alguma da bibliografia, sem pretensão de exaustividade, uma vez que esses trabalhos já resenham a questão: LE Roux 1994; ARIÑO Gil 2005; Gómez-PANTOJa 2011; CoRTÉs BÁrCENa 2013.

8 DAP, s.v. "Idanha-a-Velha".

9 CIL II, 460; Le Roux 1994, 48, nº 2; AriÑo Gil 2005, 97; Gómez-Pantoja 2011, 301, n. 23; Cortés BárCena 2013, 52-53, no6. O texto é o seguinte: Imp(erator) $\cdot$ Caesar $\cdot$ Aug(ustus) $\cdot$ pon(tifex) / max(imus) . tri(bunicia) $\cdot$ pot (estate) $\cdot$ XXVIII / co(n)s(ul) $\cdot$ XIII $\cdot$ pater $\cdot$ patr(iae $) /$ term (inus) $\cdot$ Aug (ustalis $) \cdot$ inter $\cdot$ Lanc(ienses) / Opp(idanos) $\cdot$ et $\cdot$ Igaedit(anos).

10 AE 1976, 273; Le Roux 1994, 48, nº 2; Ariño Gil 2005, 97-98; GómeZ-PantoJa 2011, 301-302, n. 25; Cortés BárCena 2013, 4-51, nº5. O texto é o seguinte: Imp(erator) - Caesar · Aug(ustus) - pontifex / max(imus) $\cdot$ trib(unicia) $\cdot$ potest(ate) $\cdot$ XXIIIX $\cdot \operatorname{co}(n) s(u l) \cdot$ XIII / pater $\cdot$ patriae $\cdot$ terminus $\cdot$ Augustâlis / inter $\cdot$ Lancienses $\cdot$ et $\cdot$ Igaeditanos.

11 Para além das abreviaturas dos etnónimos e de term. Aug., há a registar outras na titulatura imperial, ainda que as fontes modernas - Docano e Morales - não sejam neste ponto coincidentes, conforme demonstra Hübner no CIL. 
que esta não encontre eco na inscrição da ponte de Alcântara. ${ }^{12}$ Esta posição, alicerça-se em alusão pliniana a uns Lancienses sem determinativo e a uns Ocelenses que seriam também Lancienses e cujo nome completo se equaciona como Lancienses Ocelenses, de que o terminus Augustalis de Peroviseu poderia ser testemunho. ${ }^{13}$ Não obstante, estará longe de provada a irrelevância da consideração de base linguística de uma equivalência semântica entre Oppidanni e Ocelenses, através da qual se poderá concluir a existência de apenas duas comunidades de Lancienses, os Transcudani e os Oppidani, ${ }^{14}$ pelo que os termini poderiam ser referentes à separação destas com os Igaeditani. ${ }^{15}$

Isto, também admitindo que o texto do terminus Augustalis de Salvador não seja uma versão do de Peroviseu. ${ }^{16}$ E sobre este, e seu suporte, têm recaído também algumas dúvidas acerca da sua genuidade, advogando-se amiúde tratar-se de cópia, ${ }^{17}$ olhando, em grande medida, à linha que aparece no final e na qual se lê: este lettreiro estava feito no ano... Ainda que não esmiuçando a questão neste contexto, achegamos que os argumentos que se têm esgrimido a favor de o texto ser encarado como cópia não são assim tão decisivos e que se perspetiva, efetivamente, como monumento romano regravado em época moderna, ${ }^{18}$ como o próprio letreiro dá conta ao indicar que em determinado ano (o da regravação, decerto) o bloco epigrafado já existia. Os dois outros termini Augustales tem uma localização mais atlântica, associada às povoações de Ul (Oliveira de Azeméis) e Guardão (Tondela), e ambos se encontram incompletos, tendo-se perdido a referência às comunidades que neles figurariam.

Essa identificação no de U ${ }^{19}$ está facilitada pelo posicionamento geográfico claramente ocidental, sendo de admitir que referisse a separação entre Turduli Veteres, ${ }^{20}$ cuja capital poderá ter sido Langobriga, mansio a 13 milhas de Cale segundo o Itinerário de Antonino, ${ }^{21} \mathrm{e}$ o território da entidade cívica que lhe ficaria a sul. Esta poderá ter correspondido aos Paesuri, aceitando a sua localização costeira, ${ }^{22}$ ou, admitindo

12 CIL II, 760.

13 Alarcão 2005a; Carvalho 2007a, 337-345.

14 Prósper 2002, 110, n. 23; GUERRA 2007, 165-171.

15 Assim ganharia sentido a hipótese de o terminus de Peroviseu estabelecer a separação entre os Igaeditani e os Lancienses Transcudani, como já se chegou a aventar, v. g. AlARCÃo 1988, 37. Toda esta questão, assim como a conexa problemática da localização dos municipia mencionados na inscrição da ponte de Alcântara, continua a ser objeto de discussão: AlARCÃo ET ALII 2013.

16 Le Roux 1994, 48, n 2, pronunciou-se no sentido ambos corresponderem a um único documento.

17 AlarCão 1988, 35; Le Roux 1994, 48, nº 2; ENCARnAÇão 2007, 356, n. 8.

18 Evidenciam-no vestígios das letras originais discerníveis sob algumas adulterações mais notórias, como observou Curado 2006, 104-108. V. g. a haste de P de patriae sob o N que se acrescentou por incompreensão do original, derivando pater em Paternus.

19 AE 1958 10; Le Roux 1994, 48, nº 1; Ariño Gil 2005, 98; GómeZ-Pantoja 2011, 300-301, n. 21; Silva 2007, 432-433, nº 640 (epig. 55); CoRTÉs BÁrcenA 2013, 60-62, nº10. O texto é o seguinte: [Imp(eratore) Caes]are $\cdot$ Augusto $\cdot$ tribuni(cia) / [potest(ate)] $\cdot$ XXVII $\cdot \operatorname{co}(n) s($ ule $) \cdot X I I I \cdot$ pater (!) / [patr(iae) te]rminus $\cdot$ Augustalis [-- - ].

20 Silva 1983, 22; Silva 2007, 391-392.

21 Itin. Ant., 421.7; Alarcão 1988, 45; Silva 2007, 392.

22 Guerra 1998, 578; GuERra 2007, 172; Silva 2007, 392, apontando, todavia, que a localização meridional aos Turduli Veteres é centrada na região de Dão-Lafões. 
para estes uma posição mais interior e ribeirinha associada ao vale do Douro, ${ }^{23}$ aos Talabrigenses,${ }^{24}$ designação que se decalca do topónimo Talabriga ${ }^{25} \mathrm{o}$ qual, conforme se depreende da documentação viária, correspondeu à mansio da via Olisipo-Bracara Augusta que antecede Lancobriga, acima referida como situada entre os Túrdulos Velhos. Para sul, a civitas de Talabriga confinaria com a de Aeminium, cuja capital se reconhece na atual cidade de Coimbra. ${ }^{26}$ É, ainda, um par de documentos epigráficos de época augusta que permite reforçar o entendimento da localização dos Túrdulos Velhos imediatamente a sul do Douro: as tabulae do Monte Murado, ${ }^{27}$ Vila Nova de Gaia, datadas de 7 e 9 d.C., que reportam pactos de hospitalidade nos quais intervêm indivíduos indígenas integrados nesta comunidade.

Mais complexa é, todavia, a questão com o terminus de Guardão (Fig. 3). ${ }^{28}$ Embora a localização do seu achado permita equacionar que estabeleceria a divisão entre o espaço territorial atlântico meridional aos Turduli Veteri (civitas dos Paesuri ou dos referidos Talabrigenses) e a civitas que lhe ficaria a nascente, verosimilmente a dos Interannienses, ${ }^{29}$ cujo centro cívico poderá situar-se na cidade de Viseu ${ }^{30}$ também a possibilidade de marcar a fronteira entre esta e a civitas (ainda inominada) que seguramente teve a sua capital na atual povoação de Bobadela, Oliveira do Hospital, não pode ser descurada. ${ }^{31}$ Esta, não obstante ter sido apontada como eventualmente associada aos Elbocori ${ }^{32}$, poderá bem ter correspondido à dos Tapori. ${ }^{33}$

Infelizmente, a incompletude do texto não permite datar a inscrição com rigor, ainda que a historiografia recente tenda a aproximá-lo dos anos 4/6 d.C., período em que se integram os restantes termini Augustales conhecidos - 4/5 d.C.: U1 e Peroviseu; 5/6 d.C.: Salvador, Ledesma, Ciudad Rodrigo (2) e Jarandilla de Vera.

Além do mais, este terminus tem, relativamente aos restantes, a referência à intervenção de $Q$. Articuleius Regulus, legatus Augusti pro praetor, ${ }^{34}$ o governador

23 AlarCão 1990, 29-30.

24 Alarcão 1990, 27; Lopes 1995, 340; Mantas 2012, 94.

25 A sua localização tem estado sob discussão acesa nas últimas décadas, tendo vindo a apontar-se para duas localizações distintas: no Monte Marnel ou Cabeço do Vouga, no concelho de Águeda, como advogam LOPES 1995 e AlARCÃo 2004b, 325-327; no sítio de Cistelo, nas imediações de Branca, no concelho de Oliveira de Azeméis, hipótese de Mantas 1996, 624-640.

26 DAP, s. v. "Coimbra".

27 SILVA 1983; $A E 1983476$ e 477.

28 AE 1954 88; Alföldy 1969,134; Le Roux 1994, 49, nº 6; AriÑo Gil 2005, 98-100; Guerra 1998, 166-168; Gómez-PANTOJa 2011, 302-303, n. 28; Silva 2007, 433, no 641 (epig. 56); CoRTÉs BÁRCENA 2013: 66-69, $\mathrm{n}^{\circ} 12$. O texto é o seguinte: Imp (erator) $\cdot$ Caesar $\cdot \operatorname{Div}[$ if(ilius $)$ Augustus co $\left.(n) s(u l)\right] /$ XIII $\cdot$ trib(unicia $)$ - potest(ate) [- - p(ater) p(atriae) term(inum?)] / August(alem?) · inter · [- - et Interan]/ie (n)ses $\cdot Q($ uinto $) \cdot$ Artic(u)le[io Regulo leg(ato) Aug(usti)] / causa · cognit [a - - - .

29 Alarcão 1990, 27; Guerra 1998, 462-465; Alarcão 2006, 132.

30 Alarcão 1989, 305-306; Alarcão 1990, 27-28; DAP, s. v. "Viseu".

31 Alarcão 1990, 27

32 Alarcão 1990, 27; AlARCÃo 2006, 132-133, não descartando a possibilidade de esta corresponder à Veladis citada por Ptolomeu II 5.6. Mantas 2002, 232, n. 2, propõe a identificação da splendidissima civitas de Bobadela com os Interannienses.

33 Curado 1988-1994, 215; Vaz 1997, 321; Guerra 1998, 630; Curado 2004, 78 e 82; Guerra 2007, 172; CARVALHO 2007a, 151-153.

34 ALFÖLDY 1969,134. O estatuto pretoriano de Q. Articuleius Regulus parece remeter esta acção concreta para um plano da sua actividade corrente, enquadrável no âmbito das competências governativas próprias, LE 
provincial que terá intervindo nesta demarcação, em particular para resolução de qualquer pendência seguramente relacionada com limites territoriais que envolvem os Interanniensis. Este aspeto reforça o caráter oficial dos trabalhos de delimitação que os termini documentam e que a inserção do nome do imperador em cada um dos textos a par da designação qualificativa dos termini como Augustales por si só já clarifica. ${ }^{35}$

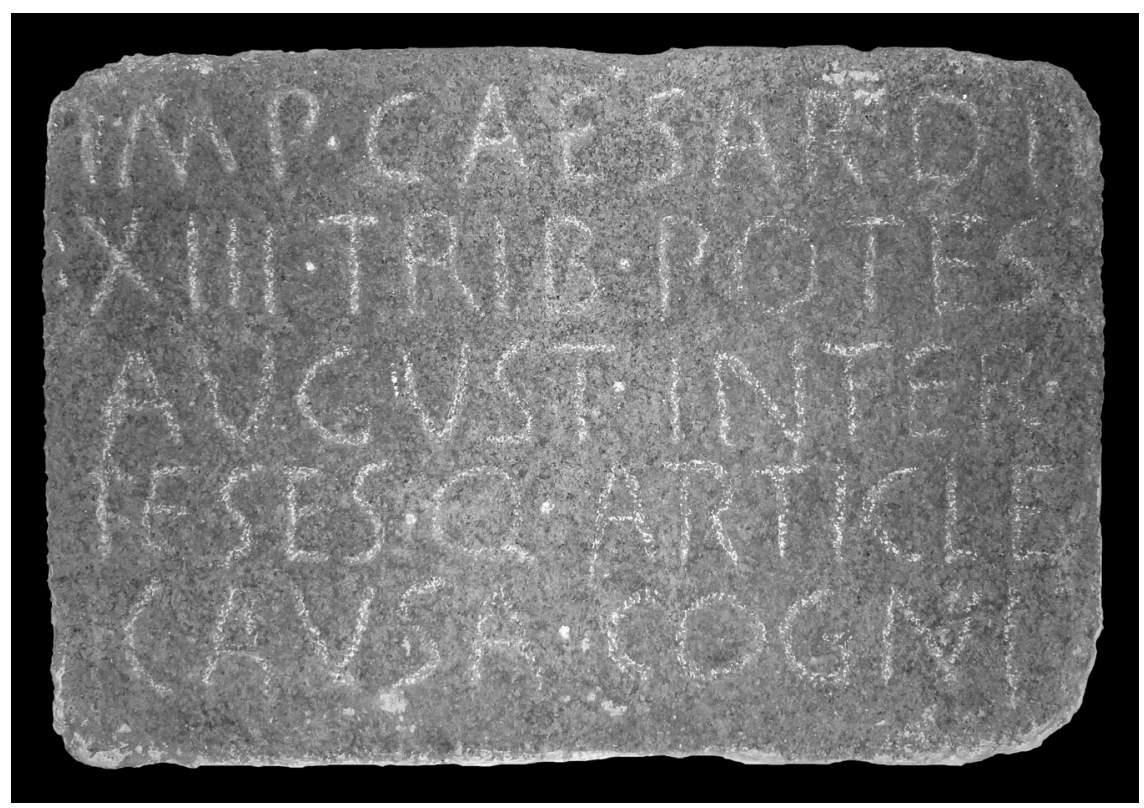

Fig. 3. Terminus Augustalis de Guardão (foto: J. Arrais).

Em suma, o conjunto dos termini Augustales referido representa o resultado de trabalhos de agrimensura levados a cabo oficialmente, sem dúvida associados à delimitação de civitates pelo método do ager per extremitatem mensura comprehensus e, decerto, com a intervenção amiudada de contingentes militares. ${ }^{36}$ Daqui se intui que, em época augustana, o Norte lusitano conheceu uma difusão generalizada do modelo político-administrativo baseado na civitas que daquela forma se materializa no território.

Todos estes termini Augustales, ao mesmo tempo que afirmam a garantia da autoridade imperial relativamente aos limites territoriais das diferentes civitates que estruturam a malha do solo provincial, consubstanciam também a projeção da imagem dessa potência no território, a qual aparece plasmada no nome do imperador,

Roux 1994, 40. Consulte-se também Elliott 2004, 29-30 e 63-64, que destaca o carácter necessariamente provisório das conclusões que se podem alcançar por intermédio deste documento devido à sua incompletude e inerentes dificuldades de restituição.

35 Le Roux 1994, 44-45; Ariño GiL 2005, 103.

36 ARIÑo GIL 2005, 103. 
presente em cada um dos termini ${ }^{37}$ e que agora apenas conhecemos enquanto blocos que claramente não se bastavam a si próprios. Seguramente estes suportes graníticos integrariam uma estrutura construída que alcançaria clara visibilidade na paisagem, mormente em pontos que seriam eixos viários estabelecidos, tratando-se possivelmente de aras monumentais, olhando à dimensão religiosa que os envolveria, subtilmente sublinhada na designação apelativa Augustalis, de sentido simultaneamente administrativo e sacral, já assinalada por diversas vezes. ${ }^{38}$

Na realidade, cada um dos textos referidos abre exatamente com o nome de Augusto, em nominativo ou ablativo, vinculando-o ao ato administrativo registado do qual é o garante por via do seu representante no governo provincial e do aparelho militar no terreno.

Como referido, boa parte ou a totalidade desta empreitada terá tido o concurso do exército, como aliás a demarcação de acessos viários documentada, no espaço territorial norte-lusitano de que tratamos, pelos miliários de Argomil (Pinhel) ${ }^{39} \mathrm{e}$ Alfaiates (Sabugal) ${ }^{40}$ confirmando que o processo de intervenção territorial é, todavia, cronologicamente mais profundo ${ }^{41}$ do que representa o processo delimitatório associado aos termini Augustales que temos vindo a referir, mesmo que a conceção deste venha sendo atribuída a Agripa. ${ }^{42}$

Estes miliários associam-se a um complexo viário que pelos territórios da Beira Interior permitia a ligação de Emerita Augusta aos espaços conventuais bracaraugustano e asturicense, cuja origem, em boa medida, se terá fundado em caminhos proto-históricos e que a conquista e integração levadas a cabo pelo poder romano reestruturam por questões de estratégia militar e de desencravamento (económico) de territórios mais recônditos. Assim o miliário de Argomil, localizado no planalto da Guarda, integra um eixo que passará a articular as civitates dos Cobelci, dos Aravi e dos Meidobrigenses, associável a via que de Caurium se desenvolvia na direção do atual território português e na qual também se pode integrar o miliário de Afaiates. ${ }^{43}$

Estes miliários destacam-se do ponto de vista formal pela sua configuração prismática e topo arredondado, em jeito de estela, e, no caso do de Alfaites, o texto foge à estrutura comum dos textos viários que anda associada estes monumentos por anteceder a identificação imperial a indicação numérica da distância que assinalava. ${ }^{44}$

37 Apenas os términos presentes em determinados pontos estratégicos seriam providos de inscrição, como os relacionados com a intercepção dos eixos viários principais com os limites territoriais cívicos, utilizando-se nos intervalos marcos mais simples. Cf. Le Roux 1994,43.

38 Le Roux 1994, 43, precisando que, decerto, a implantação destes marcadores territoriais seria objecto de cerimónias integrando ritos sacrificiais que também regularmente seriam renovados. AriÑo GIL 2005 , 103

39 Rodrigues 1980, 99-110; HEp $1682=$ HEp 15 502. O texto é o seguinte: Imp(erator) / Caesar / Divi f(ilius) / Augustûs / co(n)s(ul) XI / imp(erator) VIII.

40 AE, 1967, 185; Curado 2013, 62: C $[X X . ? X] / \operatorname{Im}[p($ erator $) /$ Caesa $[r] /$ Divi f(ilius $) /$ Augustu $[s] /$ $c[o(n) s(u l)] \mathrm{XI} /$ imp(erator) $\mathrm{V}[\mathrm{III}]$.

41 Será de referir a recente descoberta de um outro miliário prismático de época augustana em Fuenteguinaldo, já em território salmantino, dada a conhecer por SALINAS - PALAO 2012.

42 RoDÀ 1999 e 2004; AlarCão 2006, 133.

43 Mantas 2012, 245 e 250; Curado 2013, 67.

$44 \mathrm{O}$ mesmo acontece no de Fuenteguinaldo, supracitado (cf. nota 41), datável dentro de um período de tempo que medeia ente 16 e 6 a.C. e que o estado de conservação do suporte não permite precisar com maior 
Também o de Argomil se particulariza por integrar um apontamento iconográfico de grande esquematismo sob a inscrição, composto por um escudo circular flanqueado por palmas, cujo caráter insólito também terá contribuído para que tenha sido arrolado com uma dedicatória honorífica a Augusto. ${ }^{45}$ De acordo com a mais recente revisão destes documentos ${ }^{46}$ terão cronologia alta, de 23 a.C., em função do $11^{\circ}$ consulado e da $8^{\mathrm{a}}$ saudação imperial de Augusto, bem como da ausência de indicação de poder tribunício, ou, considerando esta falta como decorrente de um processo de constituição da titulatura ainda em curso, ${ }^{47}$ do período que se estende entre aquela data e 21 a.C., durante o qual Augusto ostenta oito aclamações imperiais.

A iconografia associada ao de Argomil não desmente o caráter castrense da intervenção que levou à abertura de caminhos com sentido estratégico militar-mormente para fins de vigilância e, decerto, de avaliação da importância dos recursos minerais e possibilidades de recrutamento junto da população indígena - e que posteriormente passam a integrar o complexo de itinerários essencialmente centrados na ligação Emerita Augusta-Bracara Augusta.

Em ambiente urbano, o nome de Augusto afigura-se ausente por entre a documentação epigráfica conhecida associada aos núcleos de povoamento norte-lusitanos com essa dimensão ou, pelo menos, com funções de capitalidade. Apenas a cidade dos Igaeditani conserva uma dedicatória que, embora não vise Augusto diretamente, homenageia o seu filho adotivo Gaius Caesar. ${ }^{48}$ Datada de 3/4 d.C. ${ }^{49}$ a homenagem tem paralelo noutras cidades, entre as quais cabe nomear a capital provincial lusitana,$^{50}$ sendo de relevar a relação destes testemunhos com a progressiva montagem da estrutura do culto imperial alargado pela via do culto dinástico aos herdeiros de Augusto ${ }^{51}$ uma estratégia com expressão igualmente fora do contexto lusitano, que, no Noroeste peninsular, é bem ilustrada na cidade de Bracara Augusta..$^{52} \mathrm{O}$ suporte que nos chegou corresponde a um (frontal de) pedestal, dedicado pela própria civitas Igaeditanorum para, decerto, figurar no forum que por esses anos se erguia no núcleo urbano nascido à beira do rio Ponsul. ${ }^{53}$

exactidão, segundo o estudo de SALINAS - PALAO 2012, 276.

45 VAZ 1985; AbasCAL 1996, 47.

46 CuRAdo 2013, 63, apresentando os resultados da autopsia realizada à epígrafe de Alfaiates, cuja leitura se revela problemática pelo seu estado de conservação, e apontando a sua coincidência com o texto da peça de Argomil, salvo na indicação miliária, ausente neste último.

47 Cf. Beltrán 1996, 72.

$48 A E 1961246=A E 1961350=R A P 484$. O texto é o seguinte: $C($ aio $) \cdot$ Caesari $\cdot$ Augusti $\cdot f($ ilio $) /$ pontif(ici) $\cdot \operatorname{co}(n) s(u l i) \cdot \operatorname{imp}($ eratori $) /$ principi $\cdot$ iuventutis / civitas Igaedit(anorum).

49 Após a morte do irmão L. Caesar, em 2 d.C., e antes do seu próprio falecimento em Fevereiro de 4 d.C., pois ostenta o título de imperator, aclamação recebida após a conquista da fortaleza arménia de Artagira, em Setembro de 3 d.C. (Dión 54.10a.7).

50 CIIAE 14. Em Emerita Augusta é plausível que tivesse existido um conjunto epigráfico destinado a honrar a família de M. Vipsanius Agrippa, do qual faria parte esta inscrição, bem como outras dedicadas ao próprio Agrippa, a Agrippa Postumus, a Iulia, filha de Augusto e a L. Caesar, cf. CIIAE 8, 12, 13 e 15, respectivamente.

51 EnCARNAÇÃo 2007, 352-355. Cf. nota anterior.

52 Tranoy 1981, 328; Redentor 2011, I, 396-405.

53 Carvalho 2009. 
Todavia, a existência deste núcleo urbano desde as duas últimas décadas do século I a.C. não carece de confirmação arqueológica, nem epigráfica. A célebre placa comemorativa da oferta de um relógio aos Igaeditani ${ }^{54}$ por parte de um cidadão emeritense, $Q$. Iallius Sex. f. Pap., com datação consular da primeira metade de 16 a.C. (Fig. 4), ${ }^{55}$ assim o demonstra, simbolizando que um novo tempo, ele próprio engendrado na nova era que Augusto moldava no regime imperial que protagoniza, seria agora também regulado em termos horários. ${ }^{56}$ Aliás, o ato evergético deste colono emeritense de origem itálica ${ }^{57}$ revestiu um significado simbólico e político relevante ao nível local, uma vez que a designação do lugar para a inserção do horarium no núcleo urbano em constituição leva à intervenção de quatro magistri de estatuto peregrino que nesse momento teriam a seu cargo os destinos da civitas, passando a deter o novo equipamento urbano, depois de instalado, um papel de relevo no ritmar das rotinas quotidianas, quer oficiais, quer privadas..$^{58}$ Obviamente, é também a prova evidente de que a partir da capital se inicia um processo de entretecimento de redes de sociais de poder provincial que mais tarde se perceberão ampliadas à sombra desta mesma civitas, como ilustra modelarmente atividade de C. Cantius Modestinus epigraficamente documentada. ${ }^{59}$

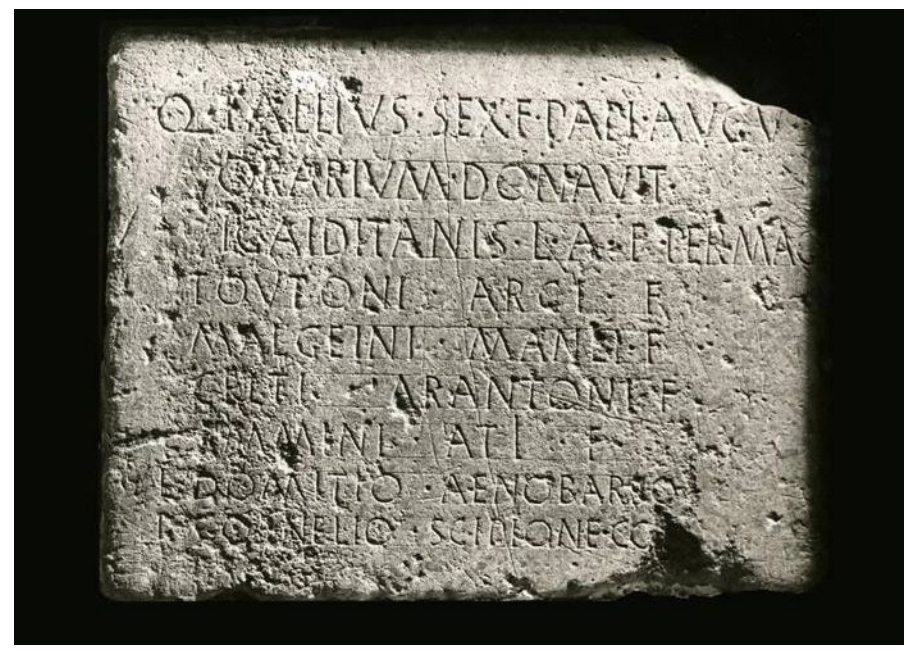

Fig. 4. Inscrição referente à oferta de um relógio à civitas Igaeditanorum (foto: Delfim Ferreira. IAFLUC/IPPAR).

54 AE 1961 349; AE 1967 144; HEp 2 770; AE 1992 951. O texto é o seguinte: Q(uintus) $\cdot$ Iallius $\cdot \operatorname{Sex}(t i)$ $\cdot f($ ilius $) \cdot$ Papi $($ ria $) \cdot A u g u($ sta $) \cdot /$ orarium $\cdot$ donavit $\cdot /$ Igaiditanis $\cdot l($ ocus $) \cdot$ a (dsignatus $) \cdot f($ uit $) \cdot \operatorname{per} \cdot \operatorname{mag}($ isterium?) $\cdot /$ Toutoni $\cdot$ Arci $\cdot f($ ilii $) \cdot /$ Malgeini $\cdot$ Manli $\cdot f($ ilii $) \cdot /$ Celti $\cdot$ Arantoni $\cdot f($ ilii $) \cdot /$ Ammini $\cdot$ Ati $\cdot f($ ilii $) \cdot$ $/$ L $($ ucio $) \cdot$ Domitio $\cdot$ Aenobarbo $\cdot /$ P $($ ublio $) \cdot$ Cornelio $\cdot$ Scipione $\cdot \operatorname{co}(n)[s($ ulibus $)]$.

55 Atendendo a que P. Cornelius P. f. Scipio não havia ainda sido substituído no cargo pelo suffectus L. Tarius Rufus. Cf. DEGRASSI 1952, 4.

56 ENCARNAÇÃo 2007, 352, com elenco da principal bibliografia sobre a inscrição.

57 Navarro Caballero et alit 2003, 409.

58 Mantas 1988, 422; ÉtIENNE 1992, 359-361.

59 Mantas 1988, 426-434; Mantas 2002. 
O registo arqueológico, por sua vez, mostra claramente que, também para estas paragens, este foi um tempo de mudança. Um tempo decisivo, marcado pela aceleração histórica, em que se sucederam as novidades. Em que dois distintos "mundos" se confrontam e se entrelaçam, em que progressivamente a cultura romana prevalece, mas sem que esta dilua muitos dos traços herdados do passado nativo. Mas também foi um tempo em que desse encontro resultaram paisagens urbanas e rurais (e sociais) com contornos distintos, mesmo no quadro estrito da província. A este nível, como veremos, mesmo quando nos focamos exclusivamente no norte da Lusitânia, a imagem que o registo arqueológico projeta para as áreas mais litorais não é idêntica àquela que se capta nas regiões mais interiores e montanhosas. ${ }^{60}$

Foquemo-nos, por agora, apenas em alguns dos exemplos mais conhecidos, por encerrarem um conjunto de dados mais amplo e, por conseguinte, por poderem ser mais representativos deste tempo de Augusto. Na faixa oceânica destacam-se Aeminium (Coimbra) e Conimbriga (Condeixa-a-Velha), capitais de civitates criadas, lado a lado, precisamente no tempo de Augusto. Ambas começam por revelar algo que será recorrente nesta região em particular: não correspondem a fundações ex nihilo, mas antes a núcleos urbanos que se instalam e desenvolvem a partir de importantes povoados da Idade do Ferro. Aliás, em toda esta região que corresponde hoje à designada Beira Litoral e também à Beira Central, é habitual verificar que muitos dos povoados pré-romanos continuam ocupados em época romana, não existindo qualquer corte ou hiato como lugar povoado, ${ }^{61}$ podendo precisamente o período augustano corresponder não ao momento de criação, mas ao de transição para um novo cenário, claramente urbano. Para além de Aeminium e Conimbriga, outros povoados, com atestada ocupação na Idade do Ferro, continuaram a ser lugares centrais em época romana: por exemplo, a splendidissima civitas de Bobadela (Oliveira do Hospital), perante os resultados alcançados em escavações recentes; ${ }^{62}$ assim como o demonstra o conjunto significativo de achados efetuados nos últimos anos em Viseu, ${ }^{63}$ a antiga *Vissaium $;{ }^{64}$ menos elucidativo será o caso do oppidum de Talabriga, ${ }^{65}$ em face da ausência de escavações recentes publicadas.

Conimbriga revela-se como cidade ao tempo de Augusto. É a partir de então, e em cerca de meio século, que se reconfigura por completo como núcleo urbano romano. Será em torno do forum augustano, enquanto núcleo central dessa cidade, que a malha urbana se desenha, repleta de novidades: ${ }^{66}$ em que desde cedo se observa a replicação de alguns modelos da arquitetura de prestígio doméstica imperial (ainda que a par da manutenção de bairros indígenas e de soluções construtivas mais vernáculas) ou em que a questão da gestão da água na cidade começa também a ser engenhosa-

\footnotetext{
60 Carvalho 2007a; Carvalho 2010a.

61 Ao contrário do que com frequência acontece na Beira Interior - Silva 2005 e CARVALHO 2007a.

62 Trabalhos arqueológicos dirigidos por Rui Marques da Silva e que decorreram no âmbito da elaboração de uma dissertação de Mestrado em Arqueologia e Território a apresentar à Faculdade de Letras da Universidade de Coimbra (2014).

63 Almeida 2005; VAZ - CARVAlHo 2009.

64 Como se pode depreender de um igualmente recente achado epigráfico: FernANDES ET ALII 2008.

65 Sobre a provável ocupação pré-romana deste lugar, podendo remontar ao Bronze Final: Silva, 2010.

66 Correia 2010.
} 
mente tratada de acordo com as soluções romanas. ${ }^{67}$ Não obstante este novo pano de fundo claramente romano, o urbanismo e a arquitetura de Conimbriga parecem assumir alguma singularidade no quadro do fenómeno urbano da Hispânia, face à manutenção de uma forte componente social indígena que não deixará de se refletir na própria morfologia romana, mediante a sobrevivência quer de algumas estruturas de propriedade, quer da própria estrutura urbana pré-romana, condicionando assim a evolução urbana da cidade romana. ${ }^{68}$

Também a cidade de Aeminium terá verdadeiramente surgido como tal, e sido promovida a capital de civitas, na época de Augusto. ${ }^{69}$ Terá sido então que Aeminium conheceu um primeiro plano de renovação urbanística e arquitetónica, implicando muito provavelmente a abertura das principais ruas ${ }^{70} \mathrm{e}$, como escavações recentes demonstraram, ${ }^{71}$ a construção do seu primeiro forum, antecedendo um de época claudiana assente num soberbo criptopórtico. ${ }^{72}$ Com efeito, também aqui, ainda que a grande reforma urbanística pareça datar de meados do séc. I d.C., vinculada ao imperador Cláudio, os primeiros sinais expressivos que documentam a presença romana inscrevem-se precisamente na época augustana, revelando-se nas primeiras alterações urbanísticas e construtivas que o local conheceu, datadas pela presença de materiais coevos, onde pontuam as terra sigilata de tipo itálico e algumas produções de paredes finas. Desta fase, no quarteirão poente contíguo ao forum, identificaram-se os traços do decumanus maximus original, de uma primeira rede de cloacas e restos de edifícios (incluindo uma possível fullonica) ${ }^{73} \mathrm{~A}$ denunciar também esse primeiro grande investimento urbano encontra-se em lugar de destaque o referido primitivo forum de Aeminium, demolido em grande parte no tempo de Cláudio, e ao qual pertenceria ainda a galeria oriental do piso superior do criptopórtico que hoje se conhece, posteriormente integrada no segundo complexo forense. ${ }^{74}$ As pré-existências, pelo menos nesta zona, parecem ter sido na totalidade apagadas, não condicionando o desenho urbano neste espaço central da cidade ${ }^{75} \mathrm{Em}$ suma, também nesta cidade, à semelhança de Conimbriga, o primeiro programa de renovação urbana data da época augustana, sendo seguido cerca de meio século depois por um outro, o qual se traduziu num maior investimento na monumentalização da cidade, a começar pelo seu centro cívico, notável pela originalidade da conceção arquitetónica e pela mestria da execução técnica ou construtiva.

67 CORReIA 2013.

68 Correia 2013, 187 ss.

69 Alarcão 2008, 29-30.

70 Carvalho et ali 2010.

71 Alarcão ET ALII 2009.

72 CarvalHo 1998.

73 Silva 2014.

74 Alarcão ET ALII 2009, 59.

75 A este propósito, será de apontar que a epigrafia associada à cidade, pese embora a exiguidade do dossiê conhecido e a cronologia algo mais tardia, parece indiciar um cenário social no qual a componente alóctone da população bem se evidencia aliada à indígena - atente-se nos casos de estudo dos Cadii e dos Vagellii, levados a cabo por LUCAS 1989 e por FERNANDES 1998, respectivamente -, aspecto que decerto não será dissociável da própria situação estratégica de Aeminium, ditada pela inserção no eixo da importante via Olisipo-Bracara Augusta e pelo fácil acesso ao oceano. 
Aeminium será uma das cidades da faixa atlântica que, logo desde a época augustana, constituirá um bom exemplo do desenvolvimento urbano e aparato arquitetónico que estas capitais de civitates irão encerrar e projetar ao longo do séc. I d.C. Paisagens urbanas com idênticos contornos, porém, não as iremos encontrar no interior do norte da Lusitânia em tempos de Augusto (e mesmo, provavelmente, ao longo de toda a primeira centúria). Aqui, em função dos dados disponíveis, a imagem que proporcionariam as capitais de civitates recentemente fundadas seria outra. Não era tanto a extensão urbana e a ostentação monumental que as distinguiria, mas antes a presença de um (único) espaço público que simbolizaria e materializaria essa capitalidade e, por conseguinte, o próprio exercício do poder imperial. Com a exceção de *Igaedis (Idanha-a-Velha) nenhum dos lugares que habitualmente é identificado como provável capital de civitas apresenta vestígios de monta que permitam supor um cenário arquitetónico particularmente extenso e elaborado - e quando estes surgem (geralmente restos do respetivo forum, acompanhados de estatuária e/ou dedicatórias imperiais), datam já do período flaviano ou sobretudo da época de Trajano, como terá acontecido muito em particular com a capital da civitas Aravorum (Marialva, Mêda). ${ }^{76}$

Em tempos de Augusto, na atual região da Beira Interior, a antiga capital da civitas Igaeditanorum terá sido um dos primeiros núcleos romanos a protagonizar uma mudança profunda no quadro do ordenamento territorial então em curso. A sede dos Igaeditani terá começado por funcionar como uma espécie de posto avançado da administração imperial numa zona que anunciava o interior norte da Lusitania. ${ }^{77}$ Fundada, possivelmente, durante a década de 30 do séc. I a.C., num lugar aparentemente vazio de povoamento, a cidade igeditana cedo terá tido um papel de capital regional federadora das comunidades adjacentes. Atuando como pólo de interlocução privilegiado com a sede provincial, terá assumido a responsabilidade de se constituir como interlocutor privilegiado entre as comunidades locais e a sede provincial, Emerita Augusta, recentemente fundada. ${ }^{78} \mathrm{O}$ seu significado e desempenho político ter-se-á projetado ainda mais quando, em torno da mudança de era, se constituirá como capital de civitas, dotada de um vasto territorium, cujos limites, como antes referimos, se assinalam no terreno no mesmo momento que se ergue o forum (Fig. 5). ${ }^{79}$

Esta simultaneidade entre monumentalização da capital e delimitação do territorium acaba por configurar um processo de profunda mudança. E essa mudança de rumo será também protagonizada pela população indígena, ${ }^{80}$ mas sem que esta se liberte da sua herança cultural. No territorium da civitas Igaeditanorum, a título de exemplo, o registo epigráfico, embora em grande medida posterior ao tempo de Augusto, aponta para numeroso conjunto de divindades indígenas, ainda que na res-

76 Alarcão 2005d, 270.

77 Mantas 2006; Carvalho 2009.

78 MANTAS 1988: 421-423; ÉTIENNE 1992: 359-362.

79 Vide supra, n. 53. A construção do forum augustano, erguido num dos sítios mais elevados da cidade, implicou a expropriação e demolição de um edifício com paredes em terra (algumas em taipa e outras em adobe), datável das últimas décadas do séc. I a.C. (CARVALHO 2013) - constatação que não deixa de remeter para uma passagem pliniana da Naturalis Historia, 35,48 , que alude à robustez da arquitectura em terra na Hispânica nesse tempo.

80 Muito bem representada na vasta epigrafia de Idanha: SÁ 2008. 
petiva capital estas estejam praticamente ausentes. ${ }^{81} \mathrm{~A}$ frequência das dedicatórias a divindades do panteão romano na capital de civitas poderá ficar-se a dever, possivelmente, à força da representação imperial e ao peso da influência de outros protagonistas vindos de fora, atraídos, desde logo, pela importância dos recursos auríferos existentes no territorium que lhe pertence ${ }^{82}$ e inscritos no quadro das redes sociais de poder provincial que se estabelecem. ${ }^{83}$

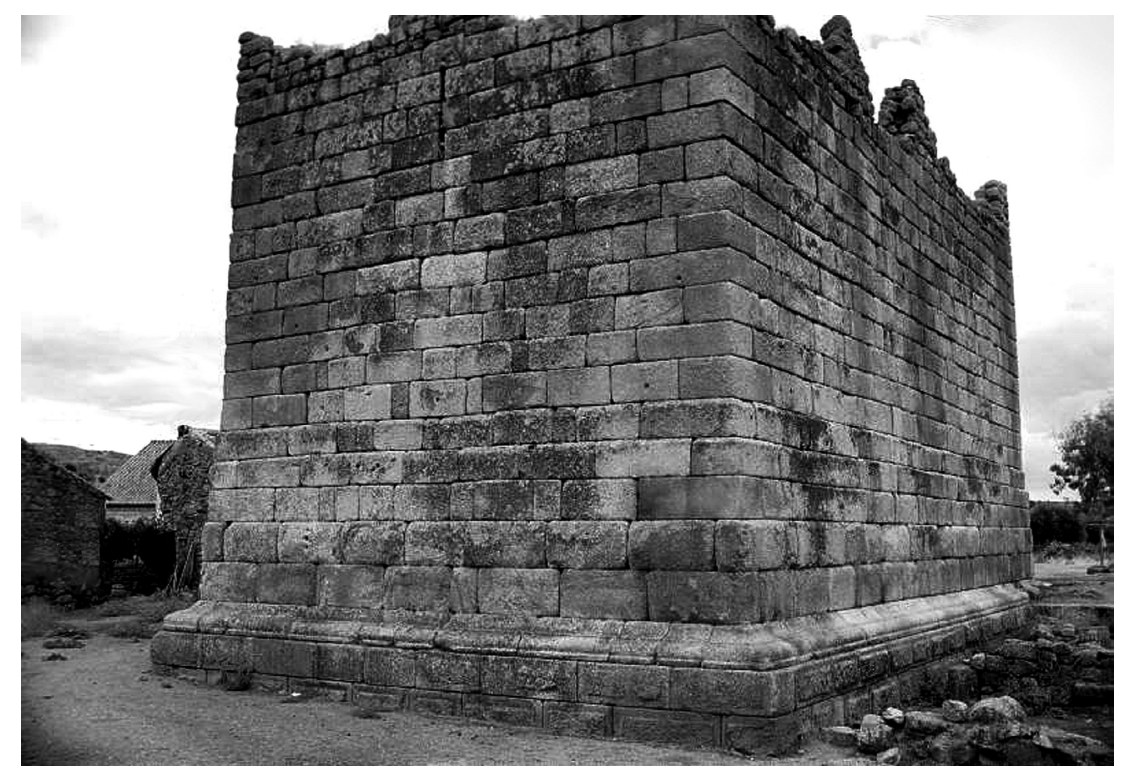

Fig. 5. Podium do templo romano de Idanha-a-Velha sob a torre do castelo templário.

Ainda a propósito da religião, um outro facto merece ser destacado, por parecer constituir uma regularidade: à semelhança do que acontecerá em Idanha, os templos dos fora das capitais desta regiões interiores parecem invariavelmente ser consagrados a Júpiter (cujas dedicatórias são também abundantes no mundo rural destas latitudes), enquanto os das cidades da faixa oceânica (tanto Conimbriga como Aeminium, ou ainda, por exemplo, de Bobadela) ${ }^{84}$ se revelam como templos do culto imperial.

Se a civitas Igaeditanorum começou a montar o cenário urbano da sua capital no tempo de Augusto (mesmo que este se resumisse a uma área de escassos hectares) as outras civitates então constituídas neste interior norte da Lusitânia poderiam mostrar-se como territoria sem urbs. Com efeito, não obstante as novas modalidades de povoamento claramente romanas que se observam, o padrão de ocupação e exploração destes territórios continua a ser marcadamente rural. O fenómeno urbano, tão característico e marcante em todo o Império, não se manifestará na região em

\footnotetext{
81 ID. $183-193$.

82 Sánchez-Palencia - Pérez García 2005, 267-307; Carvalho 2007a, 102-103, 350-353.

83 Mantas 2002; Carvalho 2010a, 85.

84 Alarcão 2002-2003.
} 
estudo de forma particularmente expressiva (e muito menos de forma exuberante). Em tempos de Augusto poderemos mesmo questionar a sistemática presença de núcleos urbanos capitais, equacionando-se antes a possibilidade de a capitalidade estar repartida por mais do que um núcleo de povoamento agrupado, onde confluíam ou se fariam representar tanto os interesses das aristocracias locais, como a presença e poder do Império. ${ }^{85}$

No extremo norte da Lusitânia, a caminho do Douro, pequenas civitates (as dos Meidubrigenses, Arabrigenses, Coilarni e Paesuri) ${ }^{86}$ repartiam esses territórios, mas sem que se lhes reconheça com clareza as respetivas capitais, em face da ausência no terreno de restos que denunciem distintamente um núcleo urbano. ${ }^{87}$ Assim, em tempos de Augusto, na ausência de centros urbanos, talvez se assistisse mesmo a uma descentralização administrativa no interior de cada civitas, repartindo-se o poder por alguns dos numerosos povoados (vici e castella) que se conhecem. Em algumas regiões próximas do Douro, a identificação de um padrão de povoamento romano assente, fundamentalmente, em povoados fortificados de altura (parecendo mesmo dar em parte continuidade a uma estrutura de povoamento anterior, proto-histórica), parece ir ao encontro desta possibilidade. E mesmo em períodos posteriores, nunca se terão formado nestas regiões em particular importantes centros urbanos, como seriam os dos Igaeditani e dos Aravi, podendo antes as capitais configurar o que a da civitas Cobelcorum (Almofala, Figueira de Castelo Rodrigo) parece exemplarmente representar ${ }^{88}$ - reforçando-se assim, também por esta via, a tese da variabilidade das paisagens provinciais. ${ }^{89}$

Por sua vez, poderemos ainda referir que, mais a sul, a capital dos Lancienses Transcudani, se esta se situar no sítio da Póvoa de Mileu (Guarda) ${ }^{90}$ não mostrou até ao momento uma ocupação expressiva da época augustana, sendo os níveis estratigráficos mais antigos, associados à construção das termas (públicas) datados de meados ou mesmo terceiro quartel do séc. I d.C., ${ }^{91}$ ainda que alguns materiais (como a terra sigilata de tipo itálico) e o seu posicionamento nas sequências estratigráficas registadas nos sugiram uma datação mais precoce, provavelmente de inícios do séc. I d.C. ${ }^{92}$

Como nova modalidade de povoamento agrupado (não necessariamente de feição urbana), a qual passará a caracterizar o padrão de povoamento do interior norte da Lusitânia, destacam-se os vici. A documentação epigráfica mostra-nos como estes es-

85 Como é proposto, aliás, para outras zonas do NO hispânico: SÁNCHEZ-PALENCIA 2000, 237-238.

86 A este propósito, Alarcão 2005b, Alarcão 2005c, VAZ 2007 e CarValHo 2010b, fundamentalmente.

87 Alarcão 2005b; Carvalho 2010b.

88 Carvalho 2007a, 338.

89 Veja-se, a este proposito, o conjunto de textos apresentados num dos suplementos do Journal of Roman Archaeology: MATTINGLY 1997; ou ainda as conclusões de dois desenvolvidos estudos territoriais sobre o NE da Lusitânia: RuIz del Árbol 2001; CARVALHo 2007a.

90 GuERra 2007.

91 Pereira 2012, 256-260.

92 Neste ponto será ainda importante referir que, em toda esta região, apenas vamos encontrar os materiais augustanos (importados) em lugares centrais, como Idanha-a-Velha e Póvoa do Mileu, estando ausentes na generalidade dos sítios escavados até ao momento. 
tabelecimentos foram relativamente habituais nestas paragens. ${ }^{93}$ Seriam mesmo uma das marcas identitárias destas paisagens provinciais. ${ }^{94} \mathrm{~A}$ interioridade destas regiões, assim como o conservadorismo da generalidade do seu substrato social, patenteado pelas comunidades locais, predominantemente autóctones, terão aconselhado ou exigido mesmo estas fundações, facto que explicará, por sua vez, a sua diferenciada distribuição pela Hispânia e pela Lusitânia em particular.

Ao entendermos que um vicus seria uma fundação oficial, um "instrumento de colonização", ${ }^{55}$ cuja fundação resultaria sempre de uma decisão institucional que visava, acima de tudo, a apropriação formal e duradoura de territórios interiores conquistados (e em particular dos seus mais relevantes recursos), não podemos deixar de os inscrever no plano de organização territorial augustano, ainda que a ausência de escavações (ou de escavações publicadas) nos lugares que epigraficamente surgem identificados como tal, impossibilite afirmar esta correspondência de forma segura. ${ }^{96}$ De todo o modo, tendo em conta alguns indicadores (mas continuando a faltar escavações estratigráficas que suportem esta possibilidade), a maioria dos vici (senão a sua totalidade) corresponderão a fundações ex nihilo - fundações que acabaram por absorver ou reunir as populações dos antigos cerros amuralhados mais próximos. ${ }^{97}$ Estrategicamente situados, quer junto à extrema dos territoria das civitates, quer no trajeto de vias imperiais (sobretudo próximo dos seus entroncamentos e de uma $m u$ tatio ou mansio), seriam lugares de mercado e palco de algumas funções administrativas e religiosas - afastados que estavam da capital da qual dependiam, reuniriam algumas das suas atribuições, constituindo-se como uma espécie de extensões desse "lugar central" ${ }^{98}$ Concorreriam, assim sendo, para exercer um controlo de maior proximidade das populações submetidas, nem sempre totalmente apaziguadas nos primeiros tempos do Império. Constituiriam, portanto, um importante pilar do modelo de ocupação do solo nesta região do interior norte da Lusitânia.

Ainda nesta região, quando se aborda a questão das paisagens rurais, outro aspeto que as caracterizará é uma - pelo menos aparente - ocupação tardia dos campos, mediante a proliferação de núcleos rurais dispersos. Com efeito, os sítios escavados que fornecem cronologias seguras para o início da sua ocupação sugerem os meados do séc. I d.C. como momento de instalação. Mesmo Centum Celas (Belmonte), não obstante a sua relevância e singularidade (face às suas características que redundam em discordâncias acerca da sua função) ${ }^{99}$ parece ter sido fundado num momento pos-

93 Le Roux 1994; Fernandes ET ALII 2006.

94 Carvalho 2010a; Carvalho 2012.

95 TARPIN 2002.

96 Ao certo, sabemos que alguns - como o vicus Venia ou Vivenia (Meimoa, Penamacor) (CurADo 1979; CURADo 2008: 125, n. 12), muito provavelmente vinculado a uma importante área de exploração aurífera existente nas proximidades (SÁNCHEZ-PALENCIA - PÉrez GARCÍA 2005, 267-307) - terão sido monumentalizados no tempo do imperador Trajano (AlARCÃo 2005a, 124; CARVAlHo 2007a, 362-366, 508, 523).

97 A relação de proximidade entre o possível vicus situado na Capinha (Fundão) e o povoado proto-histórico da Tapada das Argolas poderá configurar esta situação de abandono dos povoados de altura e de instalação dessa população nativa nas terras mais baixas (CARVALHO 2002; VILAÇA ET ALII 2002).

98 Le Roux 1994, 155-156.

99 Guerra 2007; Guerra - Schattner 2010; Alarcão 2012, 114-117; Carvalho 2012, 325-331. 
terior a Augusto. ${ }^{100}$ Idêntica cronologia inicial de construção (i.e., meados do séc. I d.C.) apresenta a quinta romana de Terlamonte (Covilhã). ${ }^{101}$ Neste lugar, assim como noutros conhecidos, a presença exclusiva de terra sigilata hispânica e a completa ausência de itálica e de outros materiais coevos, como certas formas de lucernas e cerâmicas de paredes finas, denunciam uma fase inicial de ocupação já inscrita na segunda metade do séc. I d.C. Onde (ainda que esporadicamente) se identificam materiais augustanos, estes parecem de algum modo revelar uma instalação oficial como será o caso da possível estação de muda da Raposeira (Mangualde), na qual se recolheu um importante conjunto de materiais alto-imperiais, designadamente terra sigilata de tipo itálico. ${ }^{102}$

A ser assim, se em algumas destas regiões interiores (não incluindo nestas aquelas mais a norte, na área de influência direta do Douro) a generalidade dos povoados com aparente ocupação na II Idade do Ferro não mostram sinais de ocupação romana, ${ }^{103}$ como se configurariam as paisagens rurais desta parte mais interior da Lusitânia no tempo de Augusto? Na mudança de era continuariam ocupados os povoados de outrora, mas mantendo essas comunidades nativas um mesmo repertório artefactual e cenários construídos muito arreigados ao passado, tornando difícil a identificação destes novos tempos? ${ }^{104}$ Permaneceriam os campos ocupados por casais com origem em plena Idade do Ferro, mas cujos traços, por serem ténues, ou por estarem apagados pelas ocupações posteriores, romanas, não são igualmente fáceis de detetar quando na sua grande maioria estes núcleos se conhecem apenas em face dos trabalhos de prospeção desenvolvidos? Ou será que muitos daqueles sítios romanos conhecidos (na sua grande maioria classificados como casais e villae) se distribuiram pelas terras baixas em torno da mudança de era (ao mesmo tempo que se fundavam cidades e vici, se demarcavam territórios administrativos e estruturavam vias), mas perante um singelo registo artefactual (sem materiais-tipo importados) não conseguimos atribuir a sua fundação ao período augustano? Estas são questões que só a continuidade das investigações na região, assentes em escavações (com dados publicados), poderá dar resposta.

Independentemente destas dúvidas, a investigação desenvolvida no terreno mostra que, durante o séc. I d.C., a villa não constituía o estabelecimento rural predomi-

100 FRADE 2002.

101 Carvalho 2007b.

102 Este lugar, aliás, constituirá um outro bom testemunho de um processo habitual em época augustana: a deslocalização - desde um castro (aqui situado na Nossa Senhora do Castelo, possível castellum Araocelum) a população muda-se para as terras baixas, dando lugar a um novo povoado, agora aberto e descerrado, que se desenvolveu em torno da estalagem da Raposeira situada junto ao cruzamento de duas importantes estradas imperiais (permitindo a ligação, designadamente, de *Vissaium a outras cidades vizinhas), prestando apoio aos correios e transportes da administração imperial (cursus publicus) (CARVALHo 2014).

103 E se os mostram, são já vestígios tardo-romanos.

104 Sobretudo quando a generalidade dos lugares é conhecida apenas pelos vestígios de superfície observados em prospeção. 
nante, ${ }^{105}$ proliferando antes, como referimos, as quintas ${ }^{106} \mathrm{e}$ os casais, ${ }^{107}$ por vezes agrupando-se e formando pequenos lugarejos, ${ }^{108}$ co-habitando assim com os núcleos de povoamento agrupado (vici e aldeias ou povoados amuralhados), distribuindo-se estes aglomerados populacionais por todo o norte da Lusitânia de forma marcadamente diferenciada.

O estabelecimento rural do tipo villa seria bem mais comum ao longo da faixa oceânica ${ }^{109}$ e residual em certas regiões interiores e mais montanhosas. Também as villae se distribuiriam de forma manifestamente diferenciada pela Lusitânia setentrional, mas nunca deixavam de se fazer representar. Aliás, se nos territórios interiores, logo a partir do principado de Augusto, a presença de vici pressuporá a presença de população oriunda de paragens distantes, com a incumbência de protagonizar uma efetiva exploração desses espaços, outros indicadores, ainda que raros e avulsos, parecem sugerir a instalação de uma primeira vaga de colonos associados a villae, ainda que não possamos afirmar a sua específica vinculação à época augustana, perante a ausência de elementos de datação seguros. ${ }^{110}$

A entrada no domínio romano dos territórios mais setentrionais do que viria ser a província da Lusitânia criada por Augusto representou, sem dúvida, uma alteração substancial nas estruturas políticas, sociais, económicas e culturais das populações indígenas. Sob Augusto, começaram a sentir-se as mudanças fundamentais na configuração da paisagem, desde logo ao nível da submissão do território ao modelo político administrativo da civitas, ao mesmo tempo que se elencam e registam os recursos e as potencialidades de cada nova unidade cívica, aplicando-se o método delimitatório do ager per extremitatem mensura comprehensus.

Tanto o estádio de desenvolvimento socioeconómico, como a realidade política e institucional e o ambiente cultural de cada franja territorial do Norte lusitano terão tido uma influência significativa no enraizamento de fatores identitários que se manifestam como permanências no quadro da dinâmica de mudança que a integração administrativa no contexto provincial e na dimensão imperial acarretou. E é evidente que o substrato social nativo foi responsável por um registo conservador que indicadores diversos apontam, ainda que na maioria dos casos posteriores à viragem da era, sejam eles a onomástica pessoal da população peregrina, mas também da naturalizada, a toponímia e a etnonímia, a compleição de divindades indígenas ou a sobrevivência de dialetos ou línguas pré-romanos, como bem ilustra a sobejamente divulgada inscrição rupestre do Cabeço das Fráguas (Guarda/Sabugal).

105 CARVAlHo 2007a. Assinale-se ainda que as villae, quando são claramente identificadas, parecem constituir uma manifestação tardia: veja-se o caso das villae de Vale Mouro, Mêda (CoIXÃo - SiLvino 2010) e do Prado Galego (Pinhel) (REIS - SANTOS 2006), embora não se deva descartar, segundo cremos, a possibilidade de se encontrar em ambas uma ocupação anterior.

106 CARVAlHo 2007b.

107 OSÓRIO ET ALII 2008.

108 CaRVAlHo ET ALII 2002.

109 ALARCÃo 2004a.

110 Referimo-nos à presença de mausoléus coroados por pulvini, registados nesta região não apenas em cidades, como *Igaedis, e vici, como o de Venia/Vivenia (CARVAlHo - ENCARNAÇÃo 2006), mas também junto a grandes estabelecimentos rurais, como o da villa da Fórnea (Belmonte) (SANTOS -CARVALHO 2008). 
O processo de integração teve, todavia, contornos diferenciados no litoral e no interior, conforme se depreende do registo arqueológico. Se as comunidades com territórios litorâneos rapidamente adotam o modelo urbano de clara matriz romana que se aplica sobre de importantes povoados proto-históricos, como claramente expressam os exemplos de Aeminium ou de Conimbriga, nas terras mais interiores o registo arqueológico, ainda que frequentemente mais avaro, denuncia estratégias de conformação dos parâmetros romanos do modelo de cidade dispares, adivinhandose a importância, na trama de povoamento, de fundações de vici ao lado de oppida, pelos quais se descentraliza o poder local, a cuja sediação parece servir a edificação de um simples espaço/equipamento público, com exceção da urbe dos Igaeditani, que cedo se assume como capital regional.

Em termos de povoamento, o tempo de Augusto é fortemente marcado pelas instalações oficiais, sejam os referidos vici, sejam estações viárias associadas à rede de estradas que desde cedo promove a articulação destes espaços territoriais, percecionando-se, com os dados atualmente disponíveis, que o processo de configuração das paisagens rurais com tipos de ocupação de molde romano acontece mais tardiamente, por meados do séc. I d.C., ainda que com predomínio de quintas e casais, sendo o estabelecimento do tipo villa mais comum nos territórios da faixa atlântica.

Para além das grandes obras de edificação públicas realizadas sob Augusto que se integram na trama urbana das cidades, e pelas quais perpassava a dimensão do poder e a imagem da potência imperial, quer na monumentalidade das construções, quer decerto pelos programas escultóricos a eles associados, e plausivelmente também epigráficos, nos cenários de acusada ruralidade, a imagem de Augusto não deixa de penetrar, nomeadamente por esta última via, como espelham os miliários e, sobretudo, os termini entre civitates, plasmando a sua autoridade envolta numa aura de natureza religiosa. Política e religião em convergência, uma marca indelével da gestão do fundador do império.

\section{BibLiOgRAFÍA}

Abascal, J. M. (1996): "Programas epigráficos augusteos en Hispania", Anales de Arqueología Cordobesa 7, 45-82.

$A E=$ L'Année Epigraphique, Paris.

ALARCÃo, J.

(1988): O domínio romano em Portugal, Mem Martins.

(1989): "Geografia política e religiosa da civitas de Viseu", [em] Actas do I Colóquio Arqueológico de Viseu, Viseu, 305-314.

(1990): "Identificação das cidades da Lusitânia portuguesa e dos seus territórios", [em] Les

Villes de Lusitanie romaine: hiérarchies et territoires (Table ronde internationale du CNRS

- Talence, 8-9 décembre 1988), Paris, 26-31.

(2001): "Novas perspectivas sobre os Lusitanos (e outros mundos)", Revista Portuguesa de Arqueologia 4/2, 293-349.

(2002-2003): “A splendidissima civitas de Bobadela (Lusitânia)”, Anas 15-16, 155-180. 
(2004a): In territorio Colimbrie: lugares velhos (e alguns deles deslembrados) do Mondego, Lisboa.

(2004b): "Notas de arqueologia, epigrafia e toponímia - I", Revista Portuguesa de Arqueologia 7/1, 317-342.

(2005a): "Ainda sobre a localização dos povos referidos na inscrição da ponte de Alcântara”, [em] Lusitanos e Romanos no Nordeste da Lusitânia: actas das $2^{\text {as }}$ Jornadas de Património da Beira Interior, Guarda, 119-132.

(2005b): "Povoações romanas da Beira Transmontana e do Alto Douro", Côavisão 7, 9-18. (2005c): "O território dos Paesuri e as suas principais povoações", Conimbriga 44, 147 171.

(2005d): “As cidades da Lusitânia: imagens de um processo cultural”, [em] Augusta Emerita: Territorios, Espacios, Imágenes y Gentes en Lusitania Romana, Mérida, 261-273.

(2006): "Notas de arqueologia, epigrafia e toponímia - IV", Revista Portuguesa de Arqueologia 9/1, 131-147.

(2008): Coimbra: a montagem do cenário urbano, Coimbra.

(2012): "Notas de arqueologia, epigrafia e toponímia - VI", Revista Portuguesa de Arqueologia 15, 113-137.

Alarcão, J. - André, P. - Barrelas, P. - Carvalho, P. - Santos, F. - Silva, R. C. (2009): O Forum de Aeminium: a busca do desenho original / The Forum of Aeminium: the Search for the Original Design, Lisboa.

Alarcão, J. - Barroca, M. (coords.) (2012): Dicionário de Arqueologia Portuguesa, Porto.

Alarcão, J. - Carvalho, P. C. - Madeira, J. L. - Osório, M. (2013): “O templo de Orjais (Covilhã)", Conimbriga 52, 67-128.

Alarcão, J. - Gorges, J.-G. - Mantas, V. - Salinas de Frías, M. - Sillières, P. - TraNOY, A. (1990): "Propositions pour un nouveau tracé des limites anciennes de la Lusitanie romaine", [em] Les Villes de Lusitanie romaine: hiérarchies et territoires (Table ronde internationale du CNRS - Talence, 8-9 décembre 1988), Paris, 317-329.

Alföldy, G. (1969): Fasti Hispanienses: Senatorische Reichsbeamte und Offiziere in den Spanischen Provinzen des römischen Reiches von Augustus bis Diokletian, Weisbaden.

AlmeIda, S. (2005): Idade do Ferro no planalto de Viseu: o caso do morro da Sé, (dissertação de Mestrado, policopiada, FLUC), Coimbra.

Almeida, S. - Nóbrega, J. R. - VilaçA, R. - Silva, R. C. (2014), "Cerâmica da II Idade do Ferro de Aeminium - R. Fernandes Tomás 72/74 (Coimbra, Portugal)”, Conimbriga 50, 33-57.

ArIÑo GIL, E. (2005): "La Hispania Citerior occidental y la Lusitania septentrional entre Augusto y los Flavios: el ager per extremitatem mensura comprehensus", [em] L'Aquitaine et l'Hispanie septentrionale à l'époque julio-claudienne: organisation et exploitation des espaces provinciaux. Colloque Aquitania, Bordeaux, 95-112.

BeltrÁn Lloris, F. 1996: "Un nuevo miliario y una nueva vía augústeos en Jatiel (Teruel)”, Kalathos 15, 67-78.

Carvalho, P. C.

(1998), $O$ forum de Aeminium, Lisboa.

(2007a): Cova da Beira: ocupação e exploração do território na época romana, FundãoCoimbra.

(2007b): “Terlamonte I (Teixoso, Covilhã): uma quinta romana no interior norte da Lusitania”, Conimbriga 46, 207-250. 
(2009): "O forum dos Igaeditani e os primeiros tempos da civitas Igaeditanorum (Idanha-a-Velha, Portugal)", Archivo Español de Arqueología 82, 115-131.

(2010a): "O interior norte da Lusitânia romana: resistências, mudanças e rupturas nos primeiros tempos do Império", [em] I. Sastre - A. Beltrán (eds.), El bronce de El Picón (Pino del Oro): procesos de cambio en el occidente de Hispania, Valladolid, 79-91.

(2010b): "A caminho do Douro na época romana: da capital da civitas Igaeditanorum aos territoria dos Lancienses, Araui, Meidubrigenses e Cobelci", [em] N. Cubas Martín - D. Hidalgo Rodríguez - M. Salinas de Frías (eds.), Arqueología, Patrimonio, Prehistoria e Historia Antigua de los pueblos 'sin passado': ecos de la Lusitania en Arribes del Duero (=Aquilafuente 171), Salamanca, 125-138.

(2012): "Pela Beira Interior no século I d.C.: das capitais de civitates aos vici, entre o Pônsul e a Estrela", [em] Actas do V Congresso de Arqueologia do Interior Norte e Centro de Portugal, Mêda-Foz Côa-Figueira de Castelo Rodrigo, 333-350.

(2013): "Construções em terra da época augustana na capital da civitas Igaeditanorum (Idanha-a-Velha, Idanha-a-Nova, Portugal)", digitar 1, 138-146.

(2014): "A estalagem romana da Raposeira", [em] A estalagem romana da Raposeira (Mangualde), Mangualde,14-25.

Carvalho, P. C. - Encarnação, J. d' (2006): “O monumento romano da Quinta da Caneca (Salgueiro, Fundão)", Eburobriga 4, 91-98.

Carvalho, P. C. - Matias, D. - Ramos, A. - Ribeiro, C. - Santos, F. - Silva, R. C. (2010): "Caminhando em redor do forum de Aeminium (Coimbra, Portugal)", [em] T. Nogales Basarrate (ed.), Ciudad y foro en Lusitania romana, Mérida, 69-88.

Carvalho, P. C. - Ribeiro, C. - Silva, R. - Almeida, S. (2002): "Povoamento rural romano

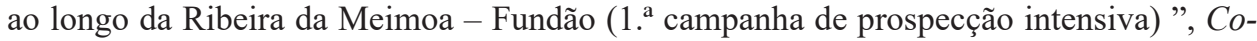
nimbriga 41, 127-152.

CIIAE = RAMÍREZ SÁDABA 2003.

$C I L$ II $=$ HÜBNER 1869 e 1892.

CoIXÃo, A. S. - Silvino, T. (2010): "Le monde agricole romain du nord du Portugal: un grand propriétaire lusitanien à Coriscada", L'Archéologue 106, 22-27.

Correia, V.

(2010): "O forum de Conimbriga e a evolução do centro urbano", [em] T. Nogales Basarrate (ed.), Ciudad y foro en Lusitania romana, Mérida, 89-106.

(2013): A arquitectura doméstica de Conimbriga e as estruturas económicas e sociais da cidade romana, Coimbra.

Cortés BÁRCEnA, C. (2013): Epigrafía en los confines de las ciudades romanas: los Termini Publici en Hispania, Mauretania y Numidia, Roma.

Curado, F. P.

(1979): "Epigrafia das Beiras", Conimbriga 18, 139-148.

(1988-94): “A propósito de Conimbriga e Coniumbriga”, [em] Actas do I Congresso Internacional sobre o rio Douro (= Gaya 6), 213-234.

(2004): “A Martim Calvo e aos povoadores do Fundão", Eburobriga 2, 77-115.

(2006): "Reflexões em torno do terminus Augustalis (dito) de Peroviseu", Eburobriga 4, 99-116.

(2008) : "Epigrafia das Beiras (Notas e correcções-2)”, Eburobriga 5, 121-148. 
(2013): "Notas sobre dois marcos miliários prismáticos, de Augusto (23 a.C.), da região da Guarda". Sabucale 5, 59-74.

$D A P=$ ALARCÃO - BARROCA 2012.

DegRassi, A. (1952) I fasti consolari dell'impero romano dal 30 avanti Cristo al 613 dopo Cristo, Roma.

Elliott, Th. (2004): Epigraphic Evidence for Boundary Disputes in the Roman Empire (PhD dissertation, University of North Carolina), Chapel Hill.

ENCARNAÇÃO, J. D’ (2007): “O culto imperial na epigrafia da Lusitânia ocidental: novidades e reflexões", [em] T. Nogales Basarrate - J. González (eds.), Culto Imperial: Política y Poder (Actas do congresso realizado no Museo Nacional de Arte Romano, Mérida, 18 19.05.2006), Roma, 350-367.

ÉtIENNE, R. (1992): “L'horloge de la civitas Igaeditanorum et la creation de la province de Lusitanie", Revue des Études Anciennes 94/3-4, 355-362.

Fernandes, L. S. (1998): Os Vagelli de Aeminium. Máthesis 7, 261-290.

Fernandes, L. - Ferreira, M. C. - Osório, M. - Perestrelo, M. (2006): “Vicus e Castellum na provincia Lusitania: notas epigráficas e arqueológicas”, Conimbriga 45, 165-198.

Fernandes, L. S. - Carvalho, P. S. - Figuera, N. (2008): "Uma nova ara votiva de Viseu (Beira Alta, Portugal)", Sylloge Epigraphica Barcinonensis 6, 185-189.

Frade, H. (2002): Centum Celas: uma villa romana na Cova da Beira (dissertação de Mestrado, policopiada, FLUC), Coimbra.

Garcia, J. M. (1991): Religiões antigas de Portugal: aditamentos e observações às Religiões da Lusitânia de J. Leite de Vasconcelos: fontes epigráficas, Lisboa.

Gómez-Pantoja, J. (2011): "Un nuevo terminus Augustalis en Lusitania”, [em] A. Sartori - A. Valvo (coord.), Identità e Autonomie nel mondo romano occidentale. Iberia-Italia Italia-Iberia: III Covegno Internazionale di Epigrafia e Storia Antica, Gargnano, 12-15 maggio 2010, Faienza, 291-317.

GuERrA, A.

(1998): Nomes pré-romanos de povos e lugares do Ocidente peninsular (tese de Doutoramento policopiada, FLUL), Lisboa.

(2007): "Sobre o território e a sede dos Lancienses (Oppidani e Transcudani) e outras questões conexas", Conimbriga 46, 161-206.

Guerra, A. - Schattner, Th. (2010): "El foro y el templo de Lancia Oppidana: nueva interpretación de Centum Celas (Belmonte)" [em] T. Nogales Basarrate (ed.), Ciudad y foro en Lusitania romana, Mérida, 333-342.

HEp = Hispania Epigraphica, Madrid.

HÜBNER, E.

(1869): Inscriptiones Hispaniae Latinae (= Corpus Inscriptionum Latinarum; 2), Berolini. (1892): Inscriptiones Hispaniae Latinae: Supplementum (= Corpus Inscriptionum Latinarum; 2), Berolini.

Lemos, F. S. (1993): O povoamento romano de Trás-os-Montes Oriental (tese de doutoramento policopiada, UM), Braga.

Lemos, F. S. - Cruz, G. - Fonte, J. (2012): “A diversidade espacial da Cultura Castreja e os limites do conventus de Bracara Augusta”, Al-Madan (2. " série) 17, 128-136. 
Le Roux, P. (1994): “Cités et territoires en Hispanie: l'épigraphie des limites”, Mélanges de la Casa de Velázquez 30/1, 37-51.

Lopes, L. S. (1995): “Talábriga: situação e limites aproximados”, Portugalia (nova série) 16, 331-343.

López Cuevillas, F. (1933): “A área xeográfica da cultura norte dos castros”, [em] Homenagem a Martins Sarmento, Guimarães, 99-107.

LuCas, M. M. (1989): “A gens Cadia em Aeminium”, Conimbriga 28, 169-203.

Mantas, V. G.

(1988), “Orarium donavit Igaiditanis: epigrafia e funções urbanas numa capital regional lusitana”, [em] Actas del I Congreso Peninsular de Historia Antigua, II, Santiago de Compostela, 415-439.

(1996): A rede viária romana da faixa atlântica entre Lisboa e Braga (Tese de Doutoramento policopiada, FLUC), Coimbra.

(2002): “C. Cantius Modestinus e seus templos”, [em] Religiões da Lusitânia: loquuntur Saxa, Lisboa, 231-234.

(2006): “Cidadania e estatuto urbano na civitas Igaeditanorum (Idanha-a-Velha)", Biblos (2. ${ }^{\mathrm{a}}$ série) $4,49-92$.

(2012): As vias romanas da Lusitânia, Mérida, 2012.

Mattingly, D. (1997) (ed.): Dialogues in Roman Imperialism: Power, Discourse and Discrepant Experience in the Roman Empire (= Journal of Roman Archaeology, Supplementary Series Number 23), Portsmouth (Rhode Island).

Navarro Caballero, M. - Oria Segura, M. - Ramírez Sádaba, J. L. (2003): "La onomástica greco-latina", [em] Grupo Mérida, Atlas antroponímico de la Lusitania romana, Mérida-Bordeaux, 407-412.

Osório, M. (2009): “A Idade do Ferro no Alto Côa: os dados e as problemáticas” [em] P. J. Sanabria Marcos (ed.), Lusitanos y vettones: los pueblos prerromanos en la actual demarcación Beira Baixa-Alentejo-Cáceres, Cáceres, 95-115.

Osório, M. - Silva, R. C. - Neves, D. - Pernadas, P. (2008): “O casal romano do Relengo (Barragem do Sabugal): elementos para o estudo do povoamento romano e tardo-romano no Vale do Côa", [em] Actas do Fórum Valorização e Promoção do Património Regional 3, Porto, 98-115.

Pereira, V. (2012): O sítio romano da Póvoa de Mileu (Guarda): povoamento, estruturas e materiais arqueológicos de uma pequena civitas localizada nos confins ocidentais do Império Romano (tese de Doutoramento policopiada, FLUC), Coimbra.

QueIRoga, F. R. (1992): War and castros: New approaches to the northwestern Portuguese Iron Age (thesis for the degree of Doctor), Oxford.

RAmírez SÁDABA, J. L. (2003): Catálogo de las inscripciones imperiales de Augusta Emerita (= Cuadernos Emeritenses 21), Mérida.

$R A P=$ Garcia 1997.

REDENTOR, A.

(2008): "Panorama da teonímia pré-romana em Trás-os-Montes Oriental”, [em] J. d'Encarnação (coord.), Divindades indígenas em análise: actas do VII Workshop FERCAN, Coimbra-Porto, 105-124. 
(2011): A cultura epigráfica no conuentus Bracaraugustanus (pars occidentalis): percursos pela sociedade brácara da época romana (tese de Doutoramento policopiada, FLUC), Coimbra.

ReIs, M. P. - SAntos, F. (2006): “A villa romana do Prado Galego: breves notas sobre a campanha de 2006", [em] III Congresso de Arqueologia de Trás-os-Montes, Alto Douro e Beira Interior - Actas 3, Pinhel, 81-84.

RoDÀ DE LlanZA, I.

(1999): "El papel de Agripa en la trama urbana de la Hispania Augustea", [em] A. Rodríguez Colmenero (coord.), Los orígenes de la ciudad en el noroeste hispánico: actas del Congreso Internacional, Lugo 15-18 de mayo de 1996, Lugo, 275-294.

(2004): "La figura de Agripa en Hispania", [em] C. Pérez González - E. Illarregui Gómez (coord.), Arqueología militar romana en Europa = Roman military archaeology in Europe: actas, Valladolid, 319-332.

Rodrigues, A. V. (1980): "Ronda do Distrito: registos de Arqueologia", Altitude (2a série) 1, 99-100.

RuIZ DEL ÁRBOL, M. (2001): Organización y explotación del territorio en el noreste de Lusitania en época Alto-imperial (Tesis Doctoral policopiada, UCM), Madrid.

SÁ, A. (2008): Civitas Igaeditanorum: os deuses e os homens, Idanha-a-Nova.

Salinas de Frías, M. - Palao Vicente, J. J. (2012): "Nuevo miliário de Augusto procedente de Fuenteguinaldo (Salamanca)", Archivo Español de Arqueologia 85, 273-279.

SÁnchez-PAlencia, F.-J. (ed.) (2000): Las Médulas (León): un paisaje cultural en la Asturia Augustana, León.

SÁnCHez-PAlencia, F.-J. - PÉRez GARCíA, L. C. (2005): "Minería romana de oro en las cuencas de los ríos Erges / Erjas y Bazágueda (Lusitania): la zona minera de Penamacor-Meimoa", [em] Actas das $2^{\text {as }}$ Jornadas de Património da Beira Interior: Lusitanos e Romanos no Nordeste da Lusitânia, Guarda, 267-307.

Santos, F. - Carvalho, P. C. (2008): "As estruturas funerárias monumentais da Quinta da Fórnea II (Belmonte): uma primeira abordagem”, Conimbriga 47, 137-153.

SiLva, A. C. F.

(1983): "As tesserae hospitales do Castro da Senhora da Saúde ou Monte Murado (Pedroso, V. N. Gaia): contributo para o estudo das instituições e povoamento da Hispânia Antiga", Gaya 1, 9-26.

(2007): A cultura castreja no Noroeste de Portugal, Paços de Ferreira.

Silva, F. P. (2010): Estação arqueológica do Cabeço do Vouga - sítio da Mina: guia da estação e do visitante, Águeda.

SILVA, R. C.

(2005): Génese e transformação da estrutura do povoamento do I milénio a. C. na Beira Interior (dissertação de Mestrado policopiada, FLUC), Coimbra.

(2014): “O quarteirão urbano a poente do forum de Aeminium (Coimbra, Portugal): a sua configuração ao longo do séc. I d.C.”, Conimbriga 50, 79-99.

SiLva, R. M. (2014): Bobadela em época romana: cidade e território periurbano, (dissertação de mestrado, policopiada, FLUC), Coimbra.

TARPIN, M. (2002): Vici et pagi dans l'Occident romain, Paris-Rome. 
Tranoy, A. (1981): La Galice romaine: recherches sur le Nord-Ouest de la Péninsule Ibérique dans l'Antiquité, Paris.

VAZ, J. I.

(1985): “Inscrição romana de Argomil (Pinhel)", Beira Alta 44/4, 635-639.

(1997): A civitas de Viseu, espaço e sociedade, Coimbra.

(2007): Lamego na época romana, capital dos Coilarnos, Lamego.

VAZ, J. I. - CARVAlho, P. S. (2009): "Viseu: a construção de um espaço urbano, do castro proto-histórico à cidade romana", [em] Viseu: cidade de Afonso Henriques, Viseu, 31-46.

Vilaça, R. - Montero Ruiz, I. - Ribeiro, C. A. - Silva, R. C. - Almeida, S. O. (2002): “A Tapada das Argolas (Capinha, Fundão): novos contributos para a sua caracterização", Estudos Pré-Históricos 10-11, 175-197. 